\title{
Seed Priming as a Method for Improving Maize Seed Germination Parameters at Low Temperatures
}

\author{
Petar Čanak* · Milan Mirosavljević · Mihajlo Ćirić · Bojana Vujošević · Jelena Kešelj · \\ Dušan Stanisavljević · Bojan Mitrović
}

Institute of Field and Vegetable Crops, Maksima Gorkog 30, 21000 Novi Sad, Serbia

\begin{abstract}
Summary: Seed priming is a useful technique, applied prior to planting, which partially hydrates the seeds to a point of germination process initiation, followed by drying, which prevents radicle emergence. The objective of this study was to evaluate the effect of various seed priming treatments on germination parameters of maize at different temperatures. Seeds were primed in water (hydropriming) and $\mathrm{KNO}_{3}$ solution $(0.1 \%$ and $0.5 \%)$ by soaking at $25^{\circ} \mathrm{C}$ for 17h. Germination parameters were tested at $25^{\circ} \mathrm{C}, 15-25^{\circ} \mathrm{C}$ and $15^{\circ} \mathrm{C}$. Seed priming had a positive effect on some seed germination parameters at low and mixed temperature. Treatment with $0.5 \% \mathrm{KNO}_{3}$ had the most improving effect. This treatment reduced MGT, $T_{50}$ and increased GE at low and mixed temperature. Priming showed no positive effect on the final germination. This study showed that seed priming with $\mathrm{KNO}_{3}$ could be used to achieve better seedling establishment at low temperature conditions in maize.

Key words: germination, maize, priming, seeds, temperature
\end{abstract}

\section{Introduction}

Maize (Zea mays L.) is one of the world's three major crops, with rice and wheat, and is geographically the most widespread of the three. It is cultivated on over $13 \%$ of the world's croplands (Leff et al., 2004). Maize originated from Mexico and is now cultivated outside its original zone of natural selection. As a thermophilic plant, maize is sensitive to low temperatures, which limits the geographical range of its cultivation. Low temperature is one of the most important environmental factors, having a great influence on crop growth, development (Venema et al., 1999), productivity (Andrews, 1987), cells ultrastructure (Kratsch \& Wise, 2000), and enzyme activity (Kang \& Saltveit, 2002). The optimal maize seed germination temperature is between $25^{\circ} \mathrm{C}$ and $28^{\circ} \mathrm{C}$. Suboptimal temperature has deleterious effects on seedling emergence and stand establishment, reduces seedling growth, relative water content, amylase activity and soluble sugars (Farooq et al., 2008c). Low temperature also lowers mitochondrial respiratory activity, electron transport and ATPase activity (Prasad et al., 1994).

Corresponding author:

petar.canak@ifvcns.ns.ac.rs

Acknowledgement:

This study is a part of the project TR 31023 financed by the Ministry of Education, Science, and Technological Development of the Republic of Serbia.
Seed priming is a useful treatment, applied prior to planting, which partially hydrates the seeds to a point of germination process initiation, followed by drying which prevents radicle emergence. Seed can be primed by either uncontrolled hydration - hydropriming (Casenave \& Tosselli, 2007; Ghassemi-Golezani et al., 2010) or controlled hydration methods which include osmotic priming, solid matrix priming and hormonal priming (Parera et al., 1993; Basra et al., 2006; Foti et al., 2008). Osmopriming involves the use of adverse osmotic solutions, like PEG or different salts such as chlorides, sulphates, nitrates, etc. Effects of seed priming with $\mathrm{KNO}_{3}$ have been previously studied in different plant species (Amjad et al., 2007; Shim et al., 2008; Eskandari \& Kazemi, 2011).

Primed seeds show increased germination rate and seedling establishment at suboptimal conditions (AlKaraki, 1998; Jafar et al., 2012). The significance of various seed priming strategies at low temperature has previously been studied. For example, PEG osmopriming improved emergence of tomato seeds (Amooaghaie et al., 2010), seed priming with $\mathrm{KNO}_{3}$ and $\mathrm{NaCl}$ decreased time to $50 \%$ germination and increased final germination of sorghum (Tiryaki \& Buyukcingil, 2009), priming with sodium selenite enhanced bitter gourd seeds germination under suboptimal temperature (Chen \& Sung, 2001), etc.

The objective of this study was to evaluate the effect of various seed priming treatments on maize germination parameters at different temperature conditions. 


\section{Material and Methods}

Maize inbred line $21 \mathrm{NS} \mathrm{Ht}$, developed at the Institute of Field and Vegetable Crops, Novi Sad, Serbia, was used as the seed source. The experiment was carried out in 2012. Seeds were primed in dishes using water (hydropriming) and two different concentrations of $\mathrm{KNO}_{3}$ solution $(0.1 \%$ and $0.5 \%)$. Priming was conducted by soaking seeds in priming solutions at $25^{\circ}$ $\mathrm{C}$ for $17 \mathrm{~h}$. Following the treatment, seeds were dried at room temperature for a few days, to the original moisture. Germination was tested in double layer rolled filter paper $(30 \mathrm{~cm} \times 30 \mathrm{~cm})$ moistened with distilled water. One set of filter papers was placed at $25^{\circ} \mathrm{C}$ (optimal temperature), second set was kept at $15^{\circ} \mathrm{C}$ (low temperature) and third set was firstly placed at $15^{\circ} \mathrm{C}$ for half of the experiment period $(84 \mathrm{~h})$ and then placed at the optimal temperature, until the end of experiment. Testing was carried out in the dark, in four replicates, with 50 seeds per replicate in completely randomized design. Rolls of filter paper were put in plastic bags to avoid moisture loss. Number of germinated seeds was recorded daily, for 7 days. Seeds were considered germinated when the radicle was $2 \mathrm{~mm}$ long.

Germination energy (GE) and final germination (FG) were recorded on 4th and 7 th day, respectively (ISTA, 2008). Mean germination time (MGT) was determined using the formula (Ellis \& Roberts, 1981):

$$
M G T=\sum D n / \sum n
$$

where $D$ is the number of days counted from the beginning of germination and $n$ is the number of seeds that had germinated on day $D$.

Time to $50 \%$ germination ( $\left.T_{50}\right)$ was calculated with the formula of Coolbear et al. (1984) modified by Farooq et al. (2005):

$$
T_{50}=t_{i}+\left(N / 2-n_{i}\right)\left(t_{j}-t_{i}\right) /\left(n_{j}-n_{i}\right)
$$

where $N$ is the final number of germinating seeds, $n_{\mathrm{j}}$ and $n_{\mathrm{i}}$ are the cumulative number of seeds germinated by adjacent counts at times $t_{\mathrm{j}}$ and $t_{\mathrm{i}}$, respectively, when $n_{\mathrm{i}}<$ $N / 2<n$.

Seedling fresh weight was measured on 7 th day. Data were processed using two-way analysis of variance, with software STATISTICA 10. Means were compared using Duncan's multiple range test (Steel \& Torrie, 1980).

\section{Results and Discussion}

All examined germination parameters were significantly affected by temperature. Low temperature and mixed temperature increased maize seed mean germination time (MGT) and time to $50 \%$ germination $\left(\mathrm{T}_{50}\right)$, and decreased germination energy (GE) in relation to optimal temperature (Table 1, 2, 3). Final germination reduction was recorded only in the case of low temperature (Table 4). Low temperature had higher influence on these parameters than mixed temperature. Seedling fresh weight was decreased by the effect of low and mixed temperature (Table 5). In this case, low temperature also had a higher diminishing effect compared to mixed temperature. Negative effect of low temperature on seed germination parameters was previously reported in different plant species (Nascimento, 2005; Malgorzata et al., 2009).

Beneficial effects of seed priming on most of the observed parameters were recorded. Seed priming treatments decreased seed MGT and $\mathrm{T}_{50}$, and increased GE of untreated seed (control). Bakht et al. (2011) reported that seed priming treatments can reduce $T_{50}$ in maize. Armin et al. (2010) found a beneficial effect of different seed priming treatments on MGT and seedling growth in watermelon. There was no effect of seed priming on final germination in this experiment. Studied seed had high germination, so there was no possibility for increasing it. Kausar et al. (2009) reported that priming treatment can significantly improve $T_{50}$ and MGT, but there was a non-significant effect on FG in normal seed of sunflower. Furthermore, priming treatment could only improve FG of low vigorous sunflower seed. The effect of seed priming on seedling fresh weight was minor compared to the effect of temperature.

Under low temperature $\left(15^{\circ} \mathrm{C}\right)$, priming treatment with $0.5 \% \mathrm{KNO}_{3}$ was the most beneficial and it significantly reduced MGT and $\mathrm{T}_{50}$, and increased GE compared to the control and other priming treatments. Farooq et al. (2008b) also found that seed priming with

Table 1. Effect of various seed priming treatments and different temperatures on maize seed mean germination time (days)

\begin{tabular}{lcccc}
\hline \multirow{2}{*}{ Seed priming treatments } & \multicolumn{2}{c}{ Temperature $\left({ }^{\circ} \mathrm{C}\right)$} & 25 & Average \\
\hline Control (untreated) & 15 & $15 / 25$ & $4.59 \mathrm{f}$ & $5.41 \mathrm{a}$ \\
Hydropriming & $6.03 \mathrm{a}$ & $5.60 \mathrm{c}$ & $4.55 \mathrm{f}$ & $5.24 \mathrm{~b}$ \\
$0.1 \% \mathrm{KNO}_{3}$ & $5.70 \mathrm{~b}$ & $5.48 \mathrm{de}$ & $4.55 \mathrm{f}$ & $5.25 \mathrm{~b}$ \\
$0.5 \% \mathrm{KNO}_{3}$ & $5.73 \mathrm{~b}$ & $5.48 \mathrm{de}$ & $4.56 \mathrm{f}$ & $5.17 \mathrm{c}$ \\
\hline Average & $5.52 \mathrm{~d}$ & $5.42 \mathrm{e}$ & $4.56 \mathrm{c}$ & - \\
\hline
\end{tabular}

Means were compared using Duncan's test; letters indicate significant difference at $\mathrm{P}<0.05$ level. 
Table 2. Effect of various seed priming treatments and different temperatures on maize seed time to $50 \%$ germination (days)

\begin{tabular}{lcccc}
\hline \multirow{2}{*}{ Seed priming treatments } & \multicolumn{2}{c}{ Temperature $\left({ }^{\circ} \mathrm{C}\right)$} & Average \\
\hline Control (untreated) & 15 & $15 / 25$ & 25 & $3.31 \mathrm{a}$ \\
Hydropriming & $4.64 \mathrm{a}$ & $3.66 \mathrm{c}$ & $1.62 \mathrm{e}$ & $3.11 \mathrm{~b}$ \\
$0.1 \% \mathrm{KNO}_{3}$ & $4.24 \mathrm{~b}$ & $3.51 \mathrm{~d}$ & $1.59 \mathrm{e}$ & $3.12 \mathrm{~b}$ \\
$0.5 \% \mathrm{KNO}_{3}$ & $4.26 \mathrm{~b}$ & $3.52 \mathrm{~d}$ & $1.57 \mathrm{e}$ & $2.92 \mathrm{c}$ \\
\hline Average & $3.72 \mathrm{c}$ & $3.45 \mathrm{~d}$ & $1.59 \mathrm{e}$ & - \\
\hline
\end{tabular}

Means were compared using Duncan's test; different letters indicate significant difference at $\mathrm{P}<0.05$ level.

salt reduced time to $50 \%$ emergence and mean emergence time and increased emergence energy in hybrid maize under low temperature. Other seed priming treatments similarly significantly improved these parameters in relation to untreated seed. These parameters indicated successful and rapid crop establishment, which is especially important in stressful condition such as low temperature. Rapid germination and emergence reduce the period of seed exposure to the attack of soil pathogens (Beckstead et al., 2007; Dalling et al., 2011). Positive effect of priming treatments on seed tolerance to low temperature and enhanced seed germination, might be attributed to an increase in activity of $\alpha$-amylase (Farooq et al., 2008a; Farooq et al., 2008b), an enzyme which rapidly hydrolyzes the starch molecules in to smaller and simple sugars (Stanley et al., 2005), important for early seedling growth. Seed priming treatments showed no improvement in final germination and seedling fresh weight at low temperature. Seed osmotic potential depends, among other factors, on soluble compound concentration (Kastori, 1984). Priming treatment may increase $\mathrm{K}^{+}$ion uptake and increasing of the osmotic potential gradient, enabling a more rapid water absorption in the seed.

At mixed temperature $\left(15 / 25^{\circ} \mathrm{C}\right)$, all priming treatments significantly reduced MGT and $\mathrm{T}_{50}$ compared to the control, and there was no difference between them. Only hydropriming improved seed germination energy. Only seed priming treatments with $0.5 \% \mathrm{KNO}_{3}$ significantly increased seedling fresh weight at mixed temperature in comparison to untreated seed. None of the priming treatments improved FG at this temperature. Mixed temperature was used in order to simulate conditions that occur in the soil after sowing. Common occurrence in Serbian regions is that suboptimal temperature conditions are followed by a sudden rise in temperature, and during that process favorable condition for seed germination are established.

At optimal germination temperature $\left(25^{\circ} \mathrm{C}\right)$, priming treatments showed no beneficial effect in all observed parameters.

Figure 1 shows different dynamics of cumulative germination, depending on temperature and priming

Table 3. Effect of various seed priming treatments and different temperatures on maize seed germination energy $(\%)$

\begin{tabular}{lcccc}
\hline Seed priming treatments & \multicolumn{2}{c}{ Temperature $\left({ }^{\circ} \mathrm{C}\right)$} & Average \\
\hline Control (untreated) & 15 & $15 / 25$ & $94.50 \mathrm{a}$ & $57.17 \mathrm{c}$ \\
Hydropriming & $5.00 \mathrm{f}$ & $72.00 \mathrm{c}$ & $97.50 \mathrm{a}$ & $72.50 \mathrm{~b}$ \\
$0.1 \% \mathrm{KNO}_{3}$ & $35.00 \mathrm{e}$ & $85.00 \mathrm{~b}$ & $95.00 \mathrm{a}$ & $69.33 \mathrm{~b}$ \\
$0.5 \% \mathrm{KNO}_{3}$ & $35.50 \mathrm{e}$ & $77.50 \mathrm{bc}$ & $96.00 \mathrm{a}$ & $78.50 \mathrm{a}$ \\
\hline Average & $58.50 \mathrm{~d}$ & $81.00 \mathrm{bc}$ & $95.75 \mathrm{a}$ & - \\
\hline
\end{tabular}

Means were compared using Duncan's test; different letters indicate significant difference at $\mathrm{P}<0.05$ level.

Table 4. Effect of various seed priming treatments and different temperatures on maize seed final germination (\%)

\begin{tabular}{|c|c|c|c|c|}
\hline \multirow{2}{*}{ Seed priming treatments } & \multicolumn{4}{|c|}{ Temperature $\left({ }^{\circ} \mathrm{C}\right)$} \\
\hline & 15 & $15 / 25$ & 25 & Average \\
\hline Control (untreated) & $91.50 \mathrm{a}$ & $95.50 \mathrm{a}$ & $95.00 \mathrm{a}$ & $94.00 \mathrm{a}$ \\
\hline Hydropriming & $92.00 \mathrm{a}$ & $98.00 \mathrm{a}$ & $97.50 \mathrm{a}$ & $95.83 \mathrm{a}$ \\
\hline $0.1 \% \mathrm{KNO}_{3}$ & $96.50 \mathrm{a}$ & $94.00 \mathrm{a}$ & $95.00 \mathrm{a}$ & $95.17 \mathrm{a}$ \\
\hline $0.5 \% \mathrm{KNO}_{3}$ & $91.50 \mathrm{a}$ & $95.50 \mathrm{a}$ & $96.00 \mathrm{a}$ & $94.33 \mathrm{a}$ \\
\hline Average & $92.88 \mathrm{~b}$ & $95.75 \mathrm{a}$ & $95.88 \mathrm{a}$ & - \\
\hline
\end{tabular}

Means were compared using Duncan's test; different letters indicate significant difference at $\mathrm{P}<0.05$ level. 
Table 5. Effect of various seed priming treatments and different temperatures on maize seed on seedling fresh weight (g)

\begin{tabular}{lcccc}
\hline \multirow{2}{*}{ Seed priming treatments } & \multicolumn{2}{c}{ Temperature $\left({ }^{\circ} \mathrm{C}\right)$} & \multicolumn{2}{c}{ Average } \\
\hline Control (untreated) & 15 & $15 / 25$ & $3.76 \mathrm{ab}$ & $2.17 \mathrm{a}$ \\
Hydropriming & $0.45 \mathrm{f}$ & $2.30 \mathrm{de}$ & $3.90 \mathrm{a}$ & $2.18 \mathrm{a}$ \\
$0.1 \% \mathrm{KNO}_{3}$ & $0.47 \mathrm{f}$ & $2.17 \mathrm{e}$ & $3.99 \mathrm{a}$ & $2.29 \mathrm{a}$ \\
$0.5 \% \mathrm{KNO}_{3}$ & $0.44 \mathrm{f}$ & $2.44 \mathrm{~cd}$ & $3.56 \mathrm{~b}$ & $2.24 \mathrm{a}$ \\
\hline Average & $0.52 \mathrm{f}$ & $2.62 \mathrm{c}$ & $3.81 \mathrm{a}$ & -
\end{tabular}

Means were compared using Duncan's test; different letters indicate significant difference at $\mathrm{P}<0.05$ level.
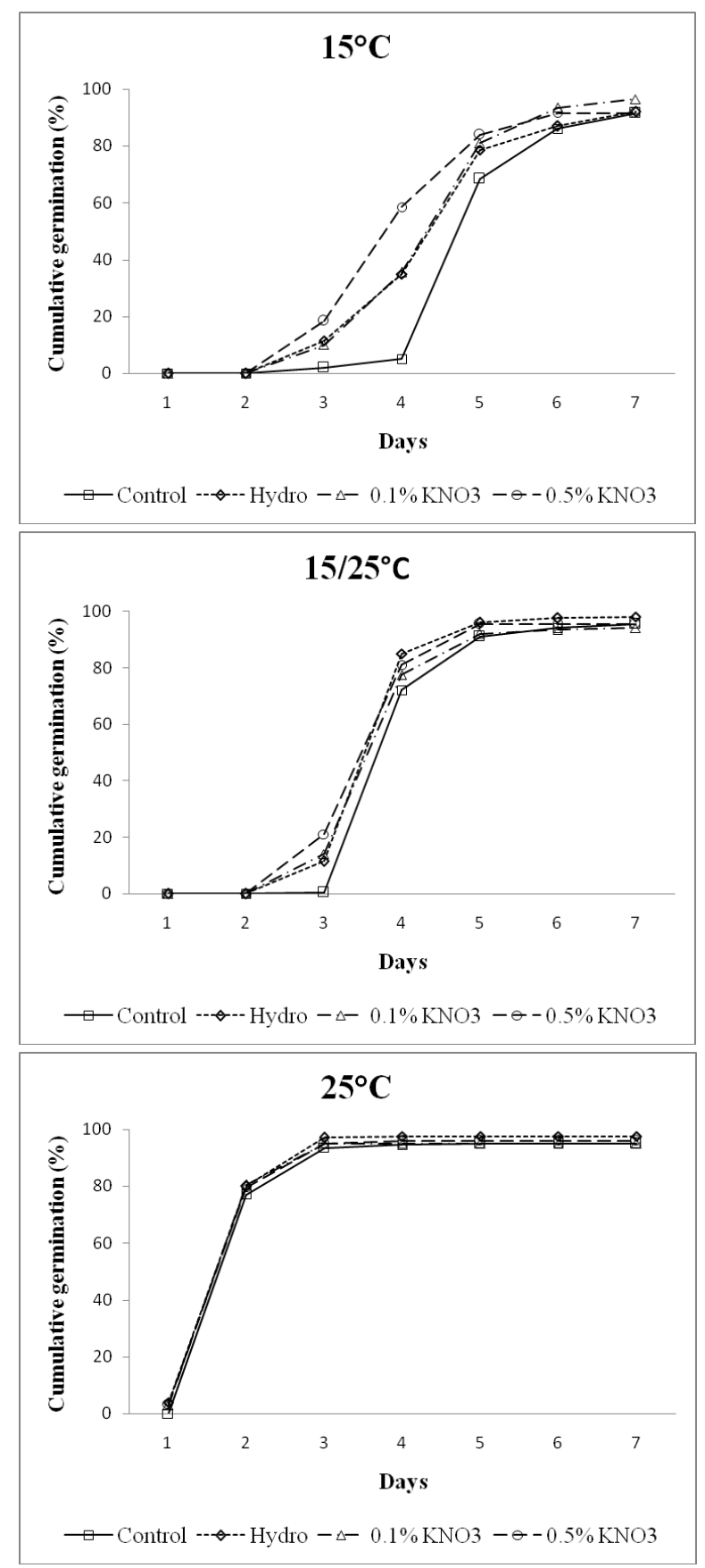

Figure 1. Cumulative germination of primed (Hydro, $0.1 \%$ $\mathrm{KNO}_{3}$ and $\left.0.5 \% \quad \mathrm{KNO}_{3}\right)$ and unprimed maize seed at different temperatures $\left(15^{\circ} \mathrm{C}, 15 / 25^{\circ} \mathrm{C}\right.$, and $\left.25^{\circ} \mathrm{C}\right)$. treatment. At low temperature, the difference between treatments was more expressed compared to the mixed temperature, while there were no obvious differences between treatments at optimal temperature. Treatment with $0.5 \% \mathrm{KNO}_{3}$ was very effective and showed more rapid germination compared to other treatments at low temperature. The greatest difference between treatments at low temperature was on 4th day, when germination energy was recorded.

\section{Conclusion}

Seed priming is a simple technique for improving seed germination parameters and early seedling growth, which reduces risk of poor crop establishment under stressful condition. The results of this study show that low temperature had a negative effect on germination parameters and seedling growth. Seed priming had a beneficial influence on some seed germination parameters at low and mixed temperature. Treatment with $0.5 \% \mathrm{KNO}_{3}$ had the most improving effect. This treatment reduced MGT, $\mathrm{T}_{50}$ and increase GE at low and mixed temperature. Priming showed no beneficial effect on seed final germination. Altogether, seed priming with $\mathrm{KNO}_{3}$ can be used to achieve better seedling establishment at low temperature conditions in maize.

\section{References}

Al-Karaki, G. N. (1998). Response of wheat and barley during germination to seed osmopriming at different water potential. Journal of Agronomy Crop Science, 181, 229-235.

Amjad, M., Ziaf, K., Iqbal, Q., Ahnad, L., Riaz, M. A., \& Saqib, Z.A. (2007). Effect of seed priming on seed vigor and salt tolerance in hot pepper. Pakistan Journal of Agricultural Sciences, 44(3), 408416.

Amooaghaie, R., Nikzad, K., \& Shareghi, B. (2010). The effect of priming on emergence and biochemical changes of tomato seeds under suboptimal temperatures. Seed Science and Technology, 38, 508-512.

Andrews, C. J. (1987). Low-temperature stress in field and forage crop production - an overview. Canadian Journal of Plant Science, 67, 1121-1133.

Armin, M., Asgharipour, M., \& Razavi-Omrani M. (2010). The effect of seed priming on germination and seedling growth of watermelon (Citrullus lanatus). Advances in Environmental Biology, 4(3), 501-505.

Bakht, J., Shafi, M., Shah, R., Raziuddin, \& Munir, I. (2011). Response of maize cultivars to various priming sources. Pakistan Journal of Agricultural Sciences, 43(1), 205-212. 
Basra, S. M. A., Farooq, M., Wahid, A., \& Khan, M. B. (2006). Rice seed invigoration by hormonal and vitamin priming. Seed Science and Technology, 34, 775-780.

Beckstead, J., Meyer, S. E., Molder, C. J., \& Smith, C. (2007). A race for survival: can Bromus tectorum seeds escape Pyrenophora semeniperdacaused mortality by germinating quickly? Annals of Botany, 99, $907-$ 914.

Casenave, E. C., \& Toselli, M. E. (2007). Hydropriming as a pre-treatment for cotton germination under thermal and water stress conditions. Seed Science and Technology, 35, 88-98.

Chen, C. C., \& Sung, J. M. (2001). Priming bitter gourd seeds with selenium solution enhances germinability and antioxidative responses under sub-optimal temperature. Physiologia Plantarum, 111, 9-16.

Coolbear, P., Francis, A., \& Grierson, D. (1984). The effect of low temperature pre-sowing treatment under the germination performance and membrane integrity of artificially aged tomato seeds. Journal of Experimental Botany, 35, 1609-1617.

Dalling, J. W., Davis, A. S., Schutte, B. J., \& Arnold, A. E. (2011). Seed survival in soil: interacting effects of predation, dormancy and the soil microbial community. Journal of Ecology, 99, 89-95.

Ellis, R. A., \& Roberts, E. H. (1981). The quantification of ageing and survival in orthodox seeds. Seed Science and Technology, 9, 373-409.

Eskandari, H., \& Kazemi, K. (2011). Effect of seed priming on germination properties and seedling establishment of cowpea ( $V$ igna sinensis). Notulae Scientia Biologicae, 3(4), 113-116.

Farooq, M., Basra, S. M. A., Hafeez, K., \& Ahmad, N. (2005). Thermal hardening: a new seed vigor enhancement tool in rice. Acta Botanica Sinica, 47, 187-193.

Farooq, M., Aziz, T., Basra, S. M. A., Wahid, A., Khaliq, A., \& Cheema, M.A. (2008a). Exploring the role of calcium to improve chilling tolerance in hybrid maize. Journal of Agronomy and Crop Science, 194, 350-359.

Farooq, M., Aziz, T., Cheema, Z. A., Hussain, M., \& Khaliq, A. (2008b). Activation of Antioxidant System by $\mathrm{KCl}$ Improves the Chilling Tolerance in Hybrid Maize. Journal of Agronomy and Crop Science, 194 438-448.

Farooq, M., Aziz, T., Hussain, M., Rehman, H., Jabran, K., \& Khan, M. B. (2008c). Glycinebetaine improves chilling tolerance in hybrid maize. Journal of Agronomy and Crop Science, 194, 152-160.

Fot, R., Abureni, K., Tigere, A., Gotosa, J., \& Gere, J. (2008). The efficacy of different seed priming osmotica on the establishment of maize (Zea mays L.) caryopses. Journal of Arid Environments, 72, 1127-1130.

Ghassemi-Golezani, K., Chadordooz-Jeddi, A., Nasrollahzadeh, S., \& Moghaddam, M. (2010). Effects of hydro-priming duration on seedling vigour and grain yield of pinto bean (Phaseolus vulgaris L.) cultivars. Notulae Botanicae Horti Agrobotanici Clij-Napoca, 38(1), 109-113.
International Seed Testing Association (2008). International rules for seed testing. Zurich, Switzerland: ISTA.

Jafar, M. Z., Farooq, M., Cheema, M. A., Afzal, I., Basra, S. M. A., Wahid, M. A., Aziz, T., \& Shahid, M. (2012). Improving the performance of wheat by seed priming under saline conditions. Journal of Agronomy and Crop Science, 198, 38-45.

Kang, H. M., \& Saltveit, M. E. (2002). Chilling tolerance of maize, cucumber and rice seedling leaves and roots are differentially affected by salicylic acid. Physiologia Plantarum, 115, 571-576.

Kausar, M., Mahmood, T., Basra, S. M. A., \& Arshad, M. (2009). Invigoration of low vigor sunflower hybrids by seed priming. International Journal of Agriculture \& Biology, 11, 521-528.

Kastori, R. (1984). Seed physiology (In Serbian). Novi Sad, Serbia: Matica Srpska.

Kratsch, H. A., \& Wise, R. R. (2000). The ultrastructure of chilling stress. Plant, Cell and Environment, 23, 337-350.

Leff, B., Ramankutty, N., \& Foley, J.A. (2004). Geographic distribution of major crops across the world. Global Biogeochemical Cycles, 18, 1-27.

Malgorzata, M., Posmyk, M., Bałabusta, M., Wieczorek, E., Sliwinska, K., \& Janas, M. (2009). Melatonin applied to cucumber (Cucumis sativus L.) seeds improves germination during chilling stress. Journal of Pineal Research, 46(2), 214-223.

Nascimento, W. M. (2005). Vegetable seed priming to improve germination at low temperature. Horticultura Brasileira, 23(2), 211-214.

Parera, C. A., Qiao, P., \& Cantliffe, D. J. (1993). Enhanced celery germination at stress temperature via solid matrix priming. HortScience, 28(1), 20-22.

Prasad, T. K., Anderson, M. D., \& Stewart, C. R. (1994). Acclimation, hydrogen peroxide, and abscisic acid protect mitochondria against irreversible chilling injury in maize seedlings. Plant Physiology, 105, 619 $-627$.

Shim, S. I., Moon, J. C., Jang, C. S., Raymer, P., \& Kim, W. (2008). Effect of potassium nitrate priming on seed germination of seashore paspalum. HortScience, 43(7), 2259-2262.

Stanley, D., Farnden, K. J. F., \& MacRae, E. A. (2005). Plant $\alpha$-amylases: functions and roles in carbohydrate metabolism. Biologia Bratislava, 60, 65-71.

Steel, R. G. D., \& Torrie, J. H. (1980). Principles and Procedures of Statistics, a Biometrical Approach. Second edition. New York, USA: Mc Graw-Hill, Book Company.

Tiryaki, I., \& Buyukcingil, Y. (2009). Seed priming combined with plant hormones: influence on germination and seedling emergence of sorghum at low temperature. Seed Science and Technology, 37, 303-315.

Venema, J. H., Posthumus, F., de Vries, M., \& Van Hasselt, P. R. (1999). Differential response of domestic and wild Lycopersicon species to chilling under low light: growth, carbohydrate content, photosynthesis and the xanthophyll cycle. Physiologia Plantarum, 105 (1), 81-88.

\section{Potapanje semena: metod za poboljšanje parametara klijanja semena kukuruza pri niskim temperaturama}

\section{Petar Čanak · Milan Mirosavljević · Mihajlo Ćirić · Bojana Vujošević · Jelena Kešelj · Dušan Stanisavljević · Bojan Mitrović}

Sažetak: Potapanje semena je metod tretmana semena. Primenjuje se neposredno pre setve, pri čemu se seme vlaži do pokretanja procesa klijanja, nakon čega se suši kako bi se sprečilo izbijanje korenka. Cilj ovog ispitivanja bila je procena efekta različitih metoda potapanja semena na parametre klijanja semena kukuruza pri različitim temperaturama. Tretman je vršen potapanjem semena u vodu i rastvore $\mathrm{KNO}_{3}(0,1 \%$ i $0,5 \%)$ pri temperaturi od $25^{\circ}$ $\mathrm{C} \mathrm{u}$ trajanju od $17 \mathrm{~h}$. Parametri klijanja praćeni su pri temperaturama $25^{\circ} \mathrm{C}, 15 / 25^{\circ} \mathrm{C}$ i $15^{\circ} \mathrm{C}$. Potapanje semena je imalo pozitivne efekte na pojedine parametre klijanja pri niskoj i kombinovanoj temperaturi. Najbolji rezultati uočeni su pri potapanju u 0,5\% $\mathrm{KNO}_{3}$. Ovaj tretman je smanjio MGT i $\mathrm{T}_{50}$ a povećao GE pri niskoj i kombinovanoj temperaturi. Potapanje semena nije uticalo na klijavost semena. Ovo istraživanje ukazuje na mogućnost primene potapanja u $\mathrm{KNO}_{3}$ u cilju postizanja bržeg nicanja i boljeg sklopa kukuruza pri nižim temperaturama.

Ključne reči: klijanje, kukuruz, potapanje, seme, temperature 